\title{
Covid-19 and the South African Pentecostal Landscape: Historic Shift from Offline Liturgical Practice to Online Platforms
}

\author{
John Mhandu and Vivian Ojong \\ MhanduJ@ukzn.ac.za \\ ojong@ukzn.ac.za
}

\section{Abstract}

The Coronavirus (Covid-19) disease resulted in an epic shift from offline liturgical practice to online platforms where South African Pentecostal churches are worshiping, using online tools such as Zoom. This article explores how offline liturgical practices, traditional power dynamics, and the performative and communication characteristics of Pentecostalism are decoded into the digital space, and the impact it has on congregants and church leadership. The self-image of South African Pentecostalism is unpacked in the context of Covid-19. Grounded in the interpretivist research paradigm, the article draws on telephonic interviews conducted with 20 purposively selected Pentecostal lay leaders and pastors in the eThekwini district, KwaZulu-Natal. The article uses the Giddens theory of structuration to understand the social structural challenges emanating from an online liturgical practice. The prohibition of gatherings to promote social distancing culminated in the use of online platforms as an alternative to physical gatherings. Key findings suggest that this historic shift created a plethora of challenges for Pentecostal churches in Durban, resulting in some being unable to reopen. Moving to online platforms meant that South African Pentecostal churches in Durban had to adapt to new modalities of practice in transmitting sacred information. By depriving Pentecostal churches the opportunity to perform rituals of solidarity and other offline liturgical practices, Covid-19 disrupted important social systems and its performative and communication traits. Despite the challenges and changes caused by this novel pandemic, this study also found that Covid-19 provided an opportunity 


\section{John Mhandu and Vivian Ojong}

to assess the doctrines of Pentecostal leaders. In other words, online worship is coupled with benefits that must not be overlooked.

Keywords: Covid-19, liturgy, offline liturgical practice, lockdown, online platforms, Pentecostal churches

\section{Introduction}

Covid-19 altered formal offline worship, forcing churches to adapt to the South African government's lockdown restrictions, including social and physical distancing measures. The article discusses the challenges and opportunities associated with the historic shift from offline to online liturgical practices. The study found that temporary sacred spaces of worship emerged in which private homes were turned into places of online worship and congregants remotely streaming live services. However, not all congregations in the Pentecostal churches shared the technical skills to positively adapt to cyberspaces of worship. With the help of technically able pastors and young congregants, many Pentecostal churches that participated in this study continued with the process of re-inventing weekly online service patterns in response to Covid-19 and lockdown restrictions. As such, despite the challenges posed by the pandemic, it created an enabling opportunity to assess the doctrines of Pentecostal leaders and the historic shift from offline liturgical practices to online platforms. Although Covid-19 deprived Pentecostal churches of the opportunity to observe rituals of solidarity and other offline liturgical practices, moving to online platforms implied that churches had to adapt to new modalities of practice in transmitting sacred information. Further, the study established that some Pentecostal churches violated lockdown restrictions, criticized the closure of churches, and continued with offline liturgical practices in cell groups.

The study documents the intersectionality of Pentecostalism with Covid-19. It argues that Pentecostalism generally acts as a reservoir of resources to which Christians turn in times of crises such as this pandemic. As a form of Christianity, it provides accounts and offers critical insights on the current situation and suggests means of mitigation. To this effect, the historic shift from offline to online liturgical practices amid the pandemic act as a medium through which Pentecostal churches create threads of connected- 
ness and togetherness. The study considers the historic shift from offline to online liturgical practices as serving a narrative-historical and symbolic purpose that enacts divine presence. As such, any contextualization of Pentecostalism, related performative traits, and its ritual aspects must consider its importance in the context of an online liturgical practice. Covid-19 and lockdown restrictions imposed by the South African government act as a practical barrier for Pentecostal churches to continue with offline liturgical practices. As such, the article argues that Pentecostal churches in Durban positively reacted to the closure of churches by adopting online and virtual forms of worship. Participating in online liturgical practices has expanded the church into the household. Households have now become the main sacred spaces for online liturgical practices.

\section{Objectives}

The article investigated the historic shift from offline to online liturgical practice. It did so by identifying selected Pentecostal churches in Durban. Drawing on the perceptions and experience of Pentecostal pastors and lay leaders in Durban, the article identified some challenges caused by Covid-19.

\section{Conceptualisation and the Nature of the Pentecostal Liturgy}

The concept of liturgy draws insights from ancient scholars. Miller (1957:326) opines that the term 'liturgy' 'comes from the Greek leitourgia, which is a combination of leitos, an adjective which means of the people (laos), and ergon, a noun which means work'. Etymologically, this means that the term 'liturgy' refers to any service performed for the universal welfare and rendered to a community. Miller (1957:326) adds that among the Hebrew and Hellenic cultures, the term 'liturgy' was used exclusively by those who worshiped Yahweh. It was mainly used by the Jewish people when referring to good things done for God's chosen people and their leaders. The term thus forms the base for establishing a relationship between people participating in the liturgy with a divine agency.

As articulated by Odo Casel (cited in Miller 1957:329), liturgy is further defined as 'a holy ritual action in which a salvific act is made present in the rite and brings salvation for the worshiping community which parti- 


\section{John Mhandu and Vivian Ojong}

cipates in it'. What this article retains from this definition is that liturgy involves the ritual triumph of the liberating work of Christ through the church. In Christian circles, the term 'liturgy' is used in relation to acts such as baptism, holy communion, healing, and deliverance, among other acts of worship. This confirms the presumption of other liturgiologists who conceptualize the term as referring to public worship.

Drawing from a Western perspective, Barnard (2010) has also examined the concept of liturgy and liminality in an attempt to explore the flows of worship in the network society. He concludes that contemporary societies are built around the center of the stability of the unstable. This implies that the liturgical elite is predominantly a 'popular movement characterised by plural authority structures' (Barnard 2010:67). According to Van Ommen (2016), there is a plethora of elements in the liturgy that relate to suffering. A safe liturgical community is therefore an essential context for anguished people to find consolation. Barnard utilizes the concept of remembrance to explain liturgy that attends to the suffering of both people and God in an attempt to explain how the common experience of suffering is related to experiences of worship.

Taking an interdisciplinary approach to the study of liturgy, the article draws on the works of Scott and Wepener (2020). The authors make a connection between three theological concepts, namely koinonia, liturgical inculturation, and the ideal of inclusivity. These concepts are comparable to the South African Pentecostal landscape and the African concept of ubuntu. The Pentecostal churches that participated in this study operate in postcolonial and pluralistic societies. As such, liturgical practice in this context requires investigating the actual liturgical praxis of worshiping communities to better understand an inclusive South African Pentecostal society. Taking a cue from Wepener (2015), both the postcolonial or post-apartheid contexts can be depicted with a pre-liminal, liminal, and post-liminal phase. Christians in this context live inclusively devoid of discrimination, hatred, and racism.

Most Pentecostal churches offer a diversity in liturgical practice, whereby pastors are empowered to perform sacred functions and regulate divine worship. In this context, the church is used as a community gathering. Miller (1957:351) states that liturgy represents the way in 'which the holy exchange between God and man [sic.] is accomplished'. This means that through liturgical practices, God descents and gives his people grace while Christians render God the utmost respect. The difference in liturgy and other 
devotional practices is grounded on the liturgy's sacramental and priestly quality (Miller 1957:352). Borrowing from Miller, this determines the way in which Pentecostal churches select acts of devotions, which are then implanted into liturgical practices. In most cases, this presumption informs the sacramental worship and connection with God.

Generally, liturgical practices include devotions, worship services, and thanksgiving, among other popular practices. These are approved and controlled by church authorities. Liturgy can therefore be summarized as the public worship of God, implementing a holy exchange of Christ's life and human respect through symbolic acts done by spiritually qualified people. The foregoing summation explains the liturgical role played by church authorities. What this article retains from the above discussion is that lay leaders and pastors are spiritually empowered to perform liturgical acts, and these are obscured in sacraments, prayer, gatherings, and mass participation. Church leaders have a spiritual qualification, which they receive through ordination and the act of baptism (Miller 1957:352). Traditionally, the abovementioned liturgical acts are performed through physical contact. The transition from physical to online liturgical practices has necessitated changes to the way in which Pentecostal churches operate, and this have caused a plethora of challenges.

\section{Online Religion vis-à-vis Religion Online}

In reflecting on liturgical practices, it is important to understand the difference between online religion and religion online. The two concepts are different and must not be misrepresented. To understand the two concepts, the article draws on the salient views of Helland (2005) and Ganiel (2021). On the one hand, Helland (2005) infers that online religion refers to all online activities that are related to religious practices. Online religion is highly interactive in cyberspace, and it is often not controlled by officials from formal institutions (Helland 2005; Ganiel 2021). On the other hand, online religion involves the widespread use of technology, which may constitute identity performances and is an opportunity to create an enabling space for religious faith (Ganiel 2021). Religion online is more easily understood in terms of the blending of online and in-person practices (Campbell 2016). It is used as a tool to transmit religious activity in the offline world (Helland 
2005). Many people practice religion online by watching performed activities that communicate their religious information. The flow of information in religion online is primarily from one platform to many people.

\section{Explaining Covid-19}

Covid-19 is a global pandemic caused by the severe acute respiratory syndrome coronavirus 2 (SARS-CoV-2). The pandemic was allegedly first discovered in Wuhan City in the Central Hubei Province in China (Shumba, Nyamaruze, Nyambuya, \& Meyer-Weitz 2020). Initially, more than 25 cases of pneumonia were reported and most of those were dealers and vendors in the Huanan seafood wholesale market (Ali, Ahmed, \& Hassan 2020). The first Covid-19 death announced was that of a 61-year-old man on January 11, 2020 (WHO 2020a). Following an increase in the number of cases and deaths, on March 11, 2020, the World Health Organization (WHO) declared Covid-19 a global health emergency (WHO 2020b). Countries responded in different ways to curb the spread of the virus. They took unprecedented measures to fight the spread of the pandemic while ameliorating its effects on the labor market and economy. Many introduced lockdown regulations, as well as social and physical distancing measures (Zirima, Nyambuya, \& Shumba 2020). However, the cases continued to spike in the comfort of lockdown in many countries (Ali et al. 2020:e2355). The spread of Covid-19 has had a significant impact on the lives of many people. Pandemics such as Covid-19 have a significant impact and social consequences that result in mobility restrictions, the closure of borders, and area quarantines (Espinoza, Castillo-Chavez, \& Perrings 2020).

The dynamics of Covid-19 cases in Africa are largely unclear, due to heterogeneous conditions and under-sampled reporting and testing (Schröder, Bossert, Kersting, Aeffner, Coetzee, Timme, \& Schlüter 2021). Further, the space for intervention to reduce the spread of the virus is weakened by the continent's economic constraints, poverty level, low rates of health literacy, weak government healthcare systems, and cultural practices. Africa's healthcare system is heavily compromised and has a very limited number of intensive care units compared to developed countries (Nkengasong \& Mankoula 2020; WHO 2020c). Weak healthcare systems influence the containment of the pandemic in Africa, coupled with several challenges bedeviling 
the African continent. Many African countries are unable to fully comply with Covid-19 containment measures such as maintaining social and physical distancing and adhering to lockdown restrictions.

In Africa, the largest number of Covid-19 confirmed cases are reported in South Africa (Schröder et al. 2021). Lockdown levels imposed by the South African government are marginally insufficient to prevent the pandemic. During consecutive waves of Covid-19, the confirmed cases have continued to increase despite lockdown measures as well as social and physical distancing measures imposed by the South African government (Mhandu \& Ojong 2020). According to the National Institute for Communicable Diseases (NICD), on July 17, 2021, a total of 14,205,299 tests were conducted across the country, and 2,283,880 laboratory-confirmed cases were recorded (NICD 2021). The NICD adds that most new cases were from Gauteng (43\%), while the Northern Cape had the least with only $1 \%$. The country has embarked on an effective vaccination program and administered approximately 5,046,267 doses of Covid-19 vaccines as on July 17, 2021 (NICD 2021). This is the largest number of doses administered in any country in Africa.

Covid-19 has affected churches in multifarious ways. Many churches moved to online worship as a containment measure (Bryson, Andres, \& Davies 2020). The shift to online liturgical practices made pastors and lay leaders innovate, adopting methods of bricolage. Bryson et al. (2020) maintain that lockdown regulations and the closure of churches in Christian denominations in the UK disallowed the engagement of shared worship and other congregational activities. Physical buildings have physical, social, and cultural symbols within Christian landscapes (Jones 2000; Miner, Bassoff, \& Moorman 2001). For Eliade (1957), the symbolic importance of a physical place of worship is grounded on its historical notion of being a place of prayer and a holy space where God resides. The closure of churches therefore has a huge impact on Pentecostal churches. To explore the interface between religion and geography, Bryson et al. (2020:21) conclude that many congergants transformed their homes into intersacred places which became places of worship. These authors developed the notion of intersacred space, analyzing how virtual services related to sacred and infrasecular places. 


\section{Theoretical Framework}

The study utilized Giddens' structuration theory (Giddens 2003). Giddens' theory of structuration is used to understand the social structural challenges emanating from an online liturgical practice. The theory provides an understanding of human action and its structure. At the core of the structuration theory is the concept of a duality of structure. According to Gafur, Soetedjo, and Triyuwono (2015:1029), Giddens borrowed the concept of the duality of structure from Karl Marx who states that men make history as human beings and not 'in circumstances of reviews their choosing'. The concept of duality thus describes the relationship between agents and structure that should not be treated independently of each other because they represent a duality. Giddens (2003) conceptualizes structure as the rules and resources organized as properties of social systems that exist only as structural properties. All social actors (re)produce their actions and understand the social systems created in the process. For Giddens (2003), the structure is characterized by properties that are either constraining or enabling to the individual. To this end, Veenstra, Melin, and Axelsson (2014) note that the duality of structures explains the reproduction of structure through repeated human actions.

The structuration theory focuses on agency and structure, and how it (un)consciously enables and/or constrains human activities within a predetermined social system. As outlined above, the concept of structure by Giddens (2003) simply refers to rules and resources. Consciousness means that human beings act with a high level of responsiveness and knowledge, which are central in the (re)production of the social system. Giddens (2003) notes that human beings employ their agency and conscious powers to (re)produce the social system. In every social system, people use structure (rules and resources) to regulate the interaction. The study used Gidden's structuration theory as an appropriate approach to a theoretical understanding of a historic shift from an offline liturgical practice to online platforms. Key to understanding this historic shift is that Pentecostalism is a Christian conscious activity that (re)produces actions and human behavior that can easily adapt to new modalities and achieve new institutional patterns. Borrowing from Giddens' theory of structuration, the study argues that Pentecostal churches may (re)produce unintended and unacknowledged consequences that serve as contextual solutions to Covid-19-related challenges, faced by Christians. As Pentecostal churches adapt to new modalities of worship, the transition to 
virtual activities will (re)produce new forms of consciousness central to transmitting sacred information.

\section{Methodology}

Grounded on the interpretivist research paradigm, the article draws on telephonic interviews conducted with 20 purposively selected Pentecostal pastors and lay leaders in the eThekwini district, KwaZulu-Natal. Nine pastors and 11 lay leaders were interviewed. In line with Covid-19 regulations to promote social and physical distancing, all interviews were conducted telephonically. Detailed notes were kept after every telephone interview. The data collection was done in two phases. The first phase was in June 2020, when the country was on lockdown alert level 5. The second phase was in March 2021 during lockdown alert level 1. During this period, the researchers also did member checking to enhance the trustworthiness of the data collected during the first phase. A non-probability snowball sampling technique was used. Dragan and Isaic-Maniu (2013) conceptualize snowball sampling as a recruitment method in which the principal investigators request participants to assist in identifying potential participants. The researchers did not use snowball sampling for generalization, it was used to have an estimated characteristic and access to Pentecostal pastors and lay leaders. This population was difficult to get, considering lockdown restrictions imposed by the national government.

Data were analyzed, using a thematic analysis. According to Alhojailan (2012), a thematic analysis provides a systematic and nuanced element to data analysis. It allows the principal investigator to obtain an analysis of the rate of recurrence of a theme. As such, the researchers accurately engaged with the recurrent theme to more widely understand the discourse of Pentecostalism and liturgical practices. How the thematic analysis was used in this study, confirms the perspectives of Namey, Guest, Thairu, and Johnson, arguing that

[t]hematic analysis moves beyond counting explicit words or phrases and focuses on identifying and describing both implicit and explicit ideas. Codes developed for ideas or themes are then applied or linked to raw data as summary markers for later analysis, which may include comparing the relative frequencies of themes or topics within a data 
set, looking for code co-occurrence, or graphically displaying code relationships (Namey et al. 2008:138).

The thematic analysis allows researchers to have a high level of precision in exploring the relationships between concepts that emerged in the study and associate them with the replicated data. The data analysis section links various concepts and opinions of Pentecostal church leaders and pastors in Durban and compares these with extant literature. The researchers also ensured that major ethical principles were observed. The researchers used pseudonyms to protect the identity of participants.

\section{Presentation and Discussion of Findings}

The following sections present and discuss the findings on a combination of both classical and neoclassical Pentecostal churches and their online liturgical practices during Covid-19 induced lockdowns in South Africa. The sections draw on data collected through telephone interviews. Most participants in this study shared their unhappiness and mentioned that the transition to the offline liturgical practice during the pandemic was coupled with a plethora of challenges. In other words, the study found that most Pentecostal churches disagreed with the closure of churches, although they adhered to the gazetted lockdown regulations. In response to a plethora of challenges posed by Covid-19 and lockdown regulations, Pentecostal churches in Durban used innovative ways to navigate the terrain and to ensure that popular traditional liturgical practices were preserved. The following sections discuss ways in which Pentecostal pastors and lay leaders controlled worship services online.

Most of the participants reiterated that Pentecostal churches cancelled events to comply with lockdown regulation and the scientific advice to avert the spread of the virus. As such, they had to shift to virtual forms of worship as an innovation. As depicted in the following sections, the shift to online platforms impacted on pertinent aspects of Pentecostalism such as ritual secrecy and legitimization. What the article retains from this presumption is that religious discourses of Pentecostal churches must intersect with scientific thoughts to promote social distancing and observe lockdown measures imposed by the South African government. The extracts in the following sections analyze the historic shift from offline liturgical practices to online 
platforms. Here, the researchers witness an increasing use of virtual platforms such as Zoom and WhatsApp for religious purposes to cope with new modalities of lockdown, as well as social and physical distancing.

\section{Pentecostal Churches as Liturgical Communities}

This section discusses how Pentecostal churches participate in liturgical practices. Pentecostal congregants gather on Sundays in church buildings and also other times of the week, mostly in houses. These gatherings create a community of worshipers that participates in liturgical practices. Before the pandemic and lockdown restrictions, Pentecostal congregants gathered to pray and perform various liturgical practices. Through performing various contact liturgical practices, the congregants created a community that became part of an unbroken tradition. As such, gathering in the church building had a sacred meaning which could not be taken away from the congregants. There is meaning attached to these church gatherings. The following extract explains the importance of church gatherings from the perspective of Pentecostal pastors in Durban: 'For us, the church is not just a building, a place where people gather for other reasons. The church is a temple of God where people gather as a unit to practice their religious rite. All our problems and misunderstandings are solved in the church and people respect the church because they know God is always in the church. God's presence is always felt in the church, and we gather in God's Name' (Telephone interview: Pastor 2, June 2020). 'For me, going to church reconnects us, and physical church gatherings are important ways of receiving grace whereby church members can witness the power of the Holy Spirit. We are called to gather and eat the body and blood of Christ through holy communion. This is only possible through physical gathering, which is not possible during lockdown. Further, it is important to note that whenever we gather, a community of Christian believers is created and this community plays an important role in our communities' (Telephone interview: Pastor 5, June 2020).

The above extracts show that some pastors believe that God is present in the church building, and by gathering there, a community of practice is created. Nikolajsen (2014:161) argues that church gatherings are formative in that they build a sense of unity. The two extracts above show that believers are not initiated into Christian life simply by reading the Bible 


\section{John Mhandu and Vivian Ojong}

from home or by faith alone. Physical interaction and gatherings play a central role in amalgamating believers into the Pentecostal community. Socialization through physical gatherings and social interaction plays an important role in creating a community of Christian believers.

Participants concurred that sacraments are important in the life of a Christian. Traditionally, this was made possible through physical gatherings. Participants believed that the holy communion is an expression of a community of caring and a way of strengthening faith. Commenting on sacraments, one of the participants said, 'For us, [holy] communion is a central practice in our church, and it helps to determine how Christians behave and act towards one another. It is also a way through which Christians acknowledge the reality of sin. Communion is a platform on which they can ask for the forgiveness of their sins. I strongly believe that a communion service requires physical or if I may call, contact church services. We believe that God is present in the church, and everyone has a right to visit the church and have access to sacramental practices, which are both social and personal (Telephone interview: Lay leader 3, June 2021).

The above narrative shows that sacraments are the Christian way in which God communicates to his people. The narrative of Lay leader 3 is an example of how this Pentecostal liturgical practice shapes the Christian life. Against this backdrop, the current article shows how liturgical communities are created through social interaction to be formative. The two liturgies discussed in this section are central to the existence of Pentecostal churches. These findings are similar to those of Nikolajsen (2014) who discusses the formative power of liturgy with specific reference to physical church gatherings and sacraments. The extract depicted in this section demonstrates how liturgy impacts on the life of Pentecostal churches. What is indisputable in this article is the theological acumen that full participation in the abovediscussed liturgical practices requires physical contact. The transition to online platforms is disrupting the ways of worship and participation in liturgical practices.

\section{Characteristics of Online Liturgical Practice}

In the context of Pentecostal churches, online liturgical practices provide a sense of togetherness and collective experience. Online platforms are used as 
a mode of communication to allow Pentecostal churches to participate in the digital world by creating new opportunities for congregants to change the theological space of the Christian church building for various spiritual needs. Lay leaders and youth members use digital platform to ensure effective communication. The participants explained the communication character of online worship and how the performative traits of Pentecostalism are transformed into the digital space. Pastor 4 related: 'Our congregants use the chat box and emojis to communicate different moments to the pastor during worship services. Normally, the lay leader is the host, and uses the mute button to maintain order and surveillance. Thus, some of the traditional power dynamics between worshipers, as well as performative aspects of Christianity are brought into the digital space. The emojis are used to express hidden voices that we normally hear in contact with church services. Pastors, lay leaders and the congregants have an option to use the emojis and chat box to send a message and in some instances, prayer requests' (Telephone interview: Pastor 4, June 2020). Pastor 6 narrated: 'Normally, all our services are not recorded for offline use. It's something that we are working on. We only use the live section through Zoom. We must rethink our strategy and ensure that services are recorded. It's something that we have never thought of trying. Our members must stay connected for the duration of the service. They use the chat box to convey a specific message, ask a question, and continue to engage with other church members during live services. After a powerful sermon or prayer, congregants send words like "amen". Amen is commonly used to express an agreement or adverbially to mean "certainly" (Telephone interview: Pastor 6, June 2020).

Findings have indicated that the online liturgical practice creates an enabling opportunity to assess the doctrines of Pentecostal pastors. The act of using the chat box and emojis to communicate different moments during online church services creates an experience of belongingness similar to offline church services. Emojis make it easy for pastors, lay leaders, and congregants to convey emotional and spiritual messages, and they are time-saving. What this article retains from the salient views of pastor 4 above is that emojis assist to substitute the hidden voice, body language, and facial signals, guaranteeing that meaning is not misconstrued. This shows that the chat box and emojis assist to maintain ritual performances and solidarity. This finding confirms Ukah's precepts where he acknowledged the importance of ritual 


\section{John Mhandu and Vivian Ojong}

performances, being socially dynamic, and solidarity as foundations of Pentecostalism and its social systems (Ukah 2020).

An analysis of pastor 6's contribution shows that Pentecostal churches use emojis in the chat box to communicate non-verbal emotions and facial expressions, connecting congregants to the online church services. What is central to the extract from pastor 6 , is the fact that effective communication during online worship is conveyed through the chat box. As an illustration, the term Amen often used in online communication means that congregants concur with the great promise from the scriptures. Further, there are emojis such as clap and fire that are reactionary to key moments during an online service. These emojis and comments in the chat box create a sense of community by prompting other congregants to engage, connect, and respond freely.

\section{Challenges Posed by Covid-19}

The study established challenges such as a loss of membership, a drop in income, members failing to adapt to online platforms, and other churches struggling to reopen when lockdown restrictions were lifted. The study established that Pentecostal churches in Durban lost their members as a result of Covid-19 and lockdown restrictions. Some members never returned when the lockdown regulations were lifted. One participant said, 'Everyone right now is tired. As lay leaders, we are tired of the pandemic that has affected our church and every aspect of our lives. For example, in my church, we lost members. After lockdown alert level 5, many people did not come back to church and for some, we even lost contact. I am told that some of our members could not withstand the challenges caused by the pandemic and they had to migrate to their countries of origin and some to their rural areas. Although the best option is to go digital, this is a big challenge to Pentecostal churches. Apart from losing members, Covid-19 has a severe psychological impact on our congregants' (Telephone interview: Lay Leader 4, March 2021). Pastor 12 added: 'Our membership was significantly affected by the lockdown and the migration to online platforms. Congregants are dealing with the loss of jobs, loss of family members, loss of livelihoods, and other challenges associated with Covid-19. As such, they could not come back to church due to unforeseen circumstances. One of the elders in my church 
recently told me that he went back to Zimbabwe because he lost his job and did not have the resources to sustain himself in South Africa. Losing membership is of great concern to the church. As a church, we recognize the scriptural concept of 1 Corinthians 12, which states that if one part suffers, every part suffers with it and if one part is honored, every part rejoices with it. This is the reason why we are concerned about the loss of membership in the church as a result of Covid-19 and lockdown restrictions' (Telephone interview: Pastor 12, March 2021).

The extracts above show that Pentecostal churches were compelled to forgo contact services and other offline liturgical practices. They experienced challenges such as a loss of membership. What is central in the two narratives is that many congregants lost their jobs and sources of livelihood, hence they had to migrate to their home countries. An analysis of Lay Leader 4's narrative shows that there are psychological challenges associated with Covid-19. The main argument is that Covid-19 lockdown restrictions on religious gatherings have a far-reaching effect on the mental health and general wellbeing of congregants.

In addition, other Pentecostal churches struggled to reopen when lockdown restrictions were lifted. In a separate interview, Lay leader 5 highlighted that their church has closed, and they were not sure when the church would reopen. The church could no longer afford to pay rentals and other bills and some members had left the church. As such, the closure of churches, the struggle to reopen, and many other challenges discussed in this section have serious psychological impacts on pastors, lay leaders, and congregants. The psychological challenges are not easily solved, using online platforms. In some instances, face-to-face counselling, which gives people enough space to express their emotions is irreplaceable.

Another participant also highlighted that the church's income dropped significantly because of the pandemic. Commenting on the financial impact of Covid-19 on churches, Lay leader 3 recounts, 'Although people want the word as well as a message of hope and restoration, the church is not only about preaching. The church has a responsibility to assist and feed people. When Covid-19 emerged, we tried to assist communities and the most affected people. However, due to a loss of membership and other challenges, our income also dropped, and we struggled to continue with this responsibility. In the last executive meeting that we had, we agreed that we 


\section{John Mhandu and Vivian Ojong}

must rethink our funding model as a solution to the economic challenges faced by the church' (Telephone interview: Lay Leader 6, March 2021).

The extract above shows that Covid-19-induced lockdowns weakened church connections, which negatively impacted on the incomes of Pentecostal churches. A loss of membership directly affects the income of the church. Many churches were heavily affected by the pandemic and the South African Council of Churches requested financial relief from the national government for member churches. Churches need income to pay rates and tax, yet their income to pay this was greatly affected. They survived due to the generosity of South Africans, NGOs, the government, and congregants. Some churches employed cost-saving measures.

\section{Disagreement with the Prohibition}

In light of the challenges discussed above, most Pentecostal lay leaders and pastors who participated in this study, disagreed with the prohibition of gatherings as a containment measure to the spread of Covid-19. The following are extracts reflecting on their views on the prohibition of gatherings: 'I strongly disagree with the closure of churches. I even circulated a message to my church members that our government has lost confidence in divine power. Those who can, I encourage them to meet in their cell groups. I can only confirm two cell groups that meet every Sunday morning. The two groups consist of the elderly who face a lot of challenges to access online platforms. They are a small, organized group of people normally staying in the same area. The rest of the cell groups operate, using online platforms. The virus is a tactic by Satan to destabilize the Christian church and we cannot allow that to happen. My fellow pastor from another church did not agree with this decision. I did what is right for me and my church. Of course, we cannot meet as a church to worship because of the lockdown regulations. As a church, we do online services' (Telephone interview: Pastor 10, June 2020). Pastor 8 related: 'Any authority that supports the closure of Christian churches is antiChrist. Given the opportunity, I would tell my followers to continue attending church services. I still do home visits providing comfort to my congregants. Some of the rituals do not require the use of technologies such as Zoom. I have members that are very old and technophobic. They are afraid of using technologies such as computers and they are not even on WhatsApp. How 
then do you expect me to invite them to Zoom services? I am of the view that as pastors, we are essential workers and this is the reason why I do home visits to my congregants, especially the aging population' (Telephone interview: Pastor 8, June 2020).

The above extracts show how some pastors and lay leaders disagreed with the prohibition of gatherings and refused to adhere to lockdown restrictions. Lockdown regulations have proved to be a challenge to some Pentecostal churches and aging congregants who find it difficult to use online platforms. The use of virtual platforms and technological affordances such as Zoom and Facebook live, neglects rituals and rites of passage wherein bodily engagement, gestures, and other systems of physical contact are of paramount importance in ritual performance. This confirms the key precepts of Van De Port (2020) who argued that online liturgical practices are considered controversial and unsuitable to the ceremonial atmosphere of the Christian church. Taking a cue from Giddens' theory of structuration (Giddens 2003), we argue that the narratives of pastors 8 and 10 demonstrate their ability to actively respond contrary to the constraining structural properties, rules, and regulations set by the nation state. They can exercise their agency and make an independent decision (that they believe) to preserve the ritual passage and rite of passage to movement of Pentecostalism amid Covid-19 restrictions.

The extracts from pastors 8 and 10 indicate a classical argument of the importance of the body and mechanical elements that enhance an offline liturgical practice. Insights are borrowed from Reinhardt (2020:1524) who is of the view that technological precepts of religion are anchored on the relation between the organic body (pastors, prophets, and lay leaders) and the mechanical elements (technology such as recorders, instruments, and speakers). The two work together to make up complete offline liturgical practices. The main argument herein is that complete ritual processes comprise physical contact, bodily engagement, and the exchange of food during sacraments. As such, an abrupt restriction on the body (such as restrictions in online liturgical practices), which is a key element of offline liturgical practices, makes some parts of the system dysfunctional. Suffice to conclude that online liturgical practices and digital platforms can to some extent constraint religious practices, making them counterproductive.

Taking a cue from the narrative by pastor 10 , it is true that in some Pentecostal churches, certain offline rituals are carried out privately, although the national government requires all churches to avoid contact sessions. In the 


\section{John Mhandu and Vivian Ojong}

case of those congregants who meet in cell groups, offline liturgical practices are carried out in a minimalistic way. A cell group is different from a church service. It has fewer members, and religious practices are performed by a small group of people.

\section{Benefits of Online Liturgical Practices}

Despite an array of challenges related to this pandemic, there are benefits that emanate from online worship. The study established some advantages of the historic shift from offline to online liturgical practices. For example, most Pentecostal churches in Durban benefited from online liturgical practices. Commenting on the advantages of online worship, one participant recounts, 'Online worship seems to be working well. We can reach an audience that could not have been reached, using physical worship. In our live sessions, this is what we have done in my church: We divide tasks in such a way that members across the globe equally participate in church services. For example, you will find that a person in Nigeria can lead praise and worship while another one in the UK leads intersession, although the preacher is in South Africa. This has worked very well for us' (Telephone interview: Pastor 7, June 2020).

The extract above shows that online worship enabled Pentecostal churches to easily connect with congregants across the globe. As such, the historic shift from offline to online platforms created an opportunity to have members in different countries to worship and participate in the same online church service. Although it can be argued that online liturgical practices and online worship are linked with increasing levels of loneliness and isolation, the study established that it created opportunities for spiritual growth. Borrowing from Giddens (2003), the introduction of online liturgical practices amid Covid-19 is situated within the ambit of overlapping social systems. This means that congregants' interaction with online worship will enact with other social structures. Online worship is an enabling opportunity for Pentecostal churches to continue with the message of hope and restoration at the same time, creating a new online community of worship.

The narrative by pastor 7 shows that online worship assists Pentecostal churches to reach a bigger audience that cannot be reached using physical worship. Congregants can follow live and recorded church services 
even when they are unable to attend it physically. Live streaming and recorded church services allow congregants to casually listen to church services as if they were listening to a radio service. On this note, one of the participants highlighted that their congregants used one mobile phone to listen to live services. This shows that family members can attend the service using one device. Thus, online liturgical practices make it easier for congregants to involve their families in the virtual service.

What is indisputable in liturgical acts is that being physically present in offline practices is only possible for people who are committed, who live close to the church building site, and those who are physically able to attend church services there. An online platform allows a larger number of congregants to participate in liturgical activities. This is because those who are unable to travel, involved in extra activities, homebound members, and all those who are not in the local vicinity of the church building, can virtually connect and join live streaming. Further, pastor 7 indicated that online worship allows for a greater engagement with church members in different countries. This compliments the earlier discussion on how church members are allowed to comment or ask questions using chat box, thus creating a room for greater engagement. In the process, an online community that allows for collaborative work is created.

\section{Analysis of the Historic Shift from Offline to Virtual Platforms}

Offline liturgical practices require physical presence to obtain the sacred energy. From the perspectives of Pentecostal lay leaders and pastors in Durban, this assertion disregards the government's moralistic pronouncement to prohibit gatherings. However, it is important to note that social and physical distancing, as well as lockdown restrictions imposed by the national government, created new avenues and modalities that permitted the proliferation of church activities such as divination and healing sessions. The main argument presented here is that the transmission of ceremonial and sacramental knowledge became more easily administrated by digital natives and sanctioned in cyberspace. To this end, online liturgical practices and strategies employed by the Pentecostal churches in Durban and which are temporary, have greater chances of setting a pattern for long-term transformation. The long-term 


\section{John Mhandu and Vivian Ojong}

transformation is a process characterized by the advent of virtual spaces which, as the article argues, play an important role in the spread of knowledge and future ritual performances. Building from the above analysis, Covid-19 and lockdown restrictions imposed by the national government, created an enabling space for Pentecostal churches in Durban to augment sacred religious values and online spaces to promote messages of hope and restoration.

The main argument presented above is that because of the Covid-19 pandemic, Pentecostal churches in Durban reinterpreted their Christian values within the context of scientific thought and digital discourses. They continued to spread messages of hope and restoration, using online platforms, concurrently observing the Covid-19 containment measures. The shift to an online liturgical practice was possible regardless of the challenges faced by stakeholders. To put it in plain words, this means that the pandemic created new modalities of worship where online spaces have become platforms of the oral transmission of sacred knowledge. This analysis is in unison with the views of Reinhardt (2020) who found that technologies and cyberspace have increasingly become important in contemporary spaces of worship. In the context of Pentecostal churches in Durban, most of the online platforms were controlled by young church members who were technologically well informed and ready to assist elderly members in the transmission of knowledge.

Furthermore, the Pentecostal churches in Durban invested a lot of resources in the management of virtual platforms and social media pages. This is supported by pastor 2 who opined that their church invested a lot of resources in purchasing Zoom licenses and required equipment to set up live church services (Telephone interview: Pastor 2, June 2020). This is not a new finding but rather confirms a study conducted by Capponi and Araújo (2020) in Brazil. In their analysis of the digital turn, the authors concluded that NeoPentecostal churches and Afro-Brazilian religions invested a lot of resources in digital divides as they occupy new online spaces amid the pandemic. The term 'digital divide', as applied to the context of this study, refers to the gap between individuals, households, businesses, and geographic areas at different socio-economic levels regarding both their opportunities to access information and communication technologies and their use of the internet for a wide variety of activities. What is key in the case of Pentecostal churches in Durban is that their investment is set to ensure that the re-appropriation of the 
digital tools does not jeopardize popular traditional liturgical practices. Rather, their approach is grounded on the fact that any investment in the digital divide should assist in the expression of spirituality and intimately connect with fellow worshippers irrespective of the impact of the virus.

\section{Conclusion}

The article discussed the impact of Covid-19 on the South African Pentecostal landscape. It investigated the historic shift from offline to online liturgical practices as set against the background of the challenges posed by the pandemic, lockdown restrictions, and social and physical containment measures imposed by the South African government. The pandemic resulted in an epic shift from offline to online platforms where South African Pentecostal churches worshiped, using online tools such as Zoom. Sacred spaces of worship emerged where homes were turned into places of online worship and congregants remotely streaming live services. Although Covid-19 deprived Pentecostal churches of the rituals of solidarity and other offline liturgical practices, the study argued that moving to online platforms meant that they had to adapt to new modalities of practice in transmitting sacred information. A thematic analysis used in this study allowed the researchers to have a high level of precision in exploring the historic shift from offline liturgical practices to online platforms.

Giddens' structuration theory as used in this article (Giddens 2003) generated an appropriate approach to a theoretical understanding of a historic shift from offline to online platforms. Based on Giddens' theoretical acumens to the context of this study, it can be argued that Pentecostal churches in Durban have the potential to (re)produce unintended and unacknowledged consequences that act as contextual solutions to Covid-19 challenges faced by human beings. Key findings suggest that this virus posed severe challenges to Pentecostal churches. However, they responded by using innovative ways to navigate the terrain and to ensure that popular traditional liturgical practices were preserved. The communication traits of worship, using online platforms such as Zoom were also explored in this article. Key findings in this regard show that the act of using chat box and emojis to communicate different moments during online church services creates an experience of belongingness. The transition and investment in the digital divide assist in the expres- 
sion of spirituality and intimately connect with fellow worshipers, despite the impact of Covid-19.

\section{References}

Alhojailan, M.I. 2012. Thematic analysis: A critical review of its process and evaluation. West East Journal of Social Sciences 1, 1: 39-47.

Ali, A., M. Ahmed, \& N. Hassan 2020. Socioeconomic impact of Covid-19 pandemic: Evidence from a rural mountain community in Pakistan. Journal of Public Affairs, August 24, 2020. e2355. doi: 10.1002/pa.2355.

Barnard, M. 2010. Flows of worship in the network society: Liminality as heuristic concept in practical theology beyond action theory. In die Skriflig 44, 1: 67-84.

Bryson, J.R., L. Andres, \& A. Davies 2020. Covid-19, virtual church services and a new temporary geography of home. Tijdschrift voor Economische en Sociale Geografie 111, 3: 360-372.

Campbell, H.A. 2016. Surveying theoretical approaches within digital religion studies. New Media \& Society 19: 15-24.

Capponi, G. \& P.C. Araújo 2020. Occupying new spaces: The 'digital turn' of Afro-Brazilian religions during the Covid-19 outbreak. International Journal of Latin American Religions 4, 2: 250-258.

Dragan, I.M. \& A. Isaic-Maniu 2013. Snowball sampling completion. Journal of Studies in Social Sciences 5, 2: 160-177.

Eliade, M. 1957. The sacred and the profane. New York: Harcourt Brace.

Espinoza, B., C. Castillo-Chavez, \& C. Perrings 2020. Mobility restrictions for the control of epidemics: When do they work? Plos one 15, 7. e0235731. doi: https://doi.org/10.1371/journal. pone.0235731.

Gafur, A., S. Soetedjo, \& I. Triyuwono 2015. Modification of structuration theory under worship concepts to construct accountability in the public sector entities. Procedia-Social and Behavioral Sciences 211: 10281035.

Ganiel, G. 2021. Online opportunities in secularizing societies? Clergy and the Covid-19 pandemic in Ireland. Religions 12, 6: 1-18.

Giddens, A. 2003. The constitution of society. London: Routledge. 
Helland, C. 2005. Online religion as lived religion: Methodological issues in the study of religious participation on the internet. Online - Heidelberg Journal of Religions on the Internet 1: 1-16. doi: 10.11588/rel. 2005.1.380.

Jones, A. 2000. A thousand years of the English parish. Moreton-in-Marsh: The Windrush Press.

Mhandu, J. \& V.B. Ojong 2020. Rethinking the complexities of decolonising curricula and humanising pedagogy in South Africa's higher education. Alternation Special Edition 36: 418-438. doi: https://doi.org/10.29086/ 2519-5476/2020/sp36a17.

Miller, J.H. 1957. The nature and definition of the liturgy. Theological Studies 18, 3: 325-356.

Miner, A.S., P. Bassof, \& C. Moorman 2001. Organizational improvisation and learning: A field study. Administrative Science Quarterly 46, 2: 304-337.

Namey, E., G. Guest, L. Thairu, \& L. Johnson 2008. Data reduction techniques for large qualitative data sets. Handbook for Team-Based Qualitative Research 2, 1: 137-161.

NICD (National Institute for Communicable Diseases). 2021. Latest confirmed cases of Covid-19 in South Africa. July 17, 2021. Available at: $\quad$ https://www.nicd.ac.za/latest-confirmed-cases-of-covid-19-insouth-africa-17-july-2021/. (Accessed on July 17, 2021.)

Nikolajsen, J.B. 2014. The formative power of liturgy: The church as a liturgical community in a post-Christendom society. European Journal of Theology 23, 2: 161-168.

Nkengasong, J.N. \& W. Mankoula 2020. Looming threat of Covid-19 infection in Africa: Act collectively, and fast. The Lancet 395: 841842.

Reinhardt, B. 2020. Atmospheric presence: Reflections on mediation in the anthropology of religion and technology. Anthropological Quarterly 93, 1: 1523-1553.

Schröder, M., A. Bossert, M. Kersting, S. Aeffner, J. Coetzee, M. Timme, \& J. Schlüter 2021. Covid-19 in South Africa: Outbreak despite interventions. Scientific Reports 11, 1:1-9.

Scott, H.R. \& C. Wepener 2020. Ubuntu in the worship service as heterotopia: A liturgical-ecclesiological exploration. In die Skriflig 54, 1: $1-6$. 
Shumba, K., P. Nyamaruze, V.P. Nyambuya, \& A. Meyer-Weitz 2020. Politicising the Covid-19 pandemic in Zimbabwe: Implications for public health and governance. African Journal of Governance \& Development 9, 1.1: 270-286.

Telephone interview: Lay leader 3, June 2021.

Telephone interview: Lay Leader 4, March 2021.

Telephone interview: Lay Leader 6, March 2021.

Telephone interview: Pastor 2, June 2020.

Telephone interview: Pastor 4, June 2020.

Telephone interview: Pastor 5, June 2020.

Telephone interview: Pastor 6, June 2020.

Telephone interview: Pastor 7, June 2020.

Telephone interview: Pastor 8, June 2020.

Telephone interview: Pastor 10, June 2020.

Telephone interview: Pastor 12, March 2021.

Ukah, A. 2020. Prosperity, prophecy and the Covid-19 pandemic: The healing economy of African Pentecostalism. Pneuma 42, 3-4: 430-459.

Van de Port, M. 2020. Moonlight. Material Religion 16, 1: 110-112.

Van Ommen, A.L. 2016. Suffering in worship: Anglican liturgy in relation to stories of suffering people. New York: Taylor \& Francis.

Veenstra, A.F., U. Melin, \& K. Axelsson 2014. Structuration theory in public sector information systems research. Proceedings of the European Conference on Information Systems (ECIS): 1-12.

Wepener, C.J. 2015. Boiling point! A faith reaction of a disillusioned nation - Reflections on anger. Wellington: Biblecor.

WHO (World Health Organization). 2020a. Pneumonia of unknown cause China. Available at: https://www.who.int/csr/don/05-january-2020pneumonia-of-unkown-cause-china/en/. (Accessed on July 23, 2021.)

WHO (World Health Organization). 2020b. Coronavirus disease 2019 (Covid-19) situation report - 46. Available at: https://www.who.int/ docs/default-source/coronaviruse/situation-reports/20200306-sitrep-46covid-19.pdf?sfvrsn=96b04adf_2. (Accessed on July 12, 2021.)

WHO (World Health Organization). 2020c. African region Covid-19 readiness status v2. Available at: https://app.powerbi.com/view? r= eyJrIjoiMzQwODk3NDYtOTIwYy00MWRjLWJiMTUtOTgzZmJmY mJmZDcxIiwidCI6ImY2MTBjMGI3LWJkMjQtN\%20GIzOS04MTBi LTNkYzI4MGFmYjU5MCIsImMiOjh9. (Accessed on July 18, 2021.) 
Zirima, H., V.P. Nyambuya, \& K. Shumba 2020. Lockdown strategies adopted by the Zimbabwean government to avert the spread of Covid19: Media responses, challenges and opportunities. African Renaissance (1744-2532), 17(3). doi: https://doi.org/10.31920/2516$5305 / 2020 / 17$ n3a13.

Dr John Mhandu Department of Sociology University of KwaZulu-Natal MhanduJ@ukzn.ac.za Prof Vivian B. Ojong School of Social Sciences University of KwaZulu-Natal ojong@ukzn.ac.za 